WHAT IS JUSTICE? 



\section{WHAT IS JUSTICE?}

JUSTIGE, LAW, AND POLITICS IN THE MIRROR OF SGIENGE Collected Essays by HANS KELSEN

UNIVERSITY OF CALIFORNIA PRES BERKELEY, LOS A NGELES, LONDON 
UNIVERSTTY OF CALIFORNLA PRESS BERKELEY AND LOS ANGELES, CALIFORNIA UNIVERSITY OF CALIFORNLA PRESS, LTD. LONDON, ENGLAND

(C), 1957, BY

THE REGENTS OF THE UNIVERSTTY OF CALIFORNIA

CALIFORNIA LIBRARY FEPRINT SERIES EDITION 1971 ISBN: 0-520-01925-3

LIBRARY OF CONGRESS CATALOG CARD NUMBER: 56-8474

PRINTED IN THE UNITED STATES OF AMERICA DESIGNED BY JOHN B. GOETZ

23456789 